Fishes of the Western North Atlantic 


\section{Publications of the Sears Foundation for Marine Research, Yale University}

The Sears Foundation for Marine Research at Yale University was established in 1937 by Albert E. Parr, director of Yale's Bingham Oceanographic Laboratory, through a gift from Henry Sears, to promote research and publication in marine sciences. The Foundation's Memoirs, inaugurated in 1948, remain important references. In 1959 the Bingham Oceanographic Collection was incorporated into the Yale Peabody Museum of Natural History.

Distributed by Yale University Press

www.yalebooks.com | yalebooks.co.uk

MEMOIR I

Fishes of the Western North AtLantic

Part One

Lancelets, Cyclostomes, Sharks

Part Two

Sawfishes, Guitarfishes, Skates and Rays, Chimaeroids

Part Three

Soft-rayed Bony Fishes: Orders Acipenseroidei, Lepisostei, and Isospondyli

Sturgeons, Gars, Tarpon, Ladyfish, Bonefish, Salmon, Charrs,

Anchovies, Herring, Shads, Smelt, Capelin, et al.

Part Four

Soft-rayed Bony Fishes: Orders Isospondyli and Giganturoidei

Argentinoids, Stomiatoids, Pickerels, Bathylaconids, Giganturids

Part Five

Orders Iniomi and Lyomeri

Lizardfishes, Other Iniomi, Deepsea Gulpers

Part Six

Orders Heteromi (Notacanthiformes), Berycomorphi (Beryciformes),

Xenoberyces (Stephanoberyciformes), Anacanthini (Gadiformes)

Halosauriforms, Killifishes, Squirrelfishes and Other Beryciforms,

Stephanoberyciforms, Grenadiers

Part Seven

Order Iniomi (Myctophiformes)

Neoscopelids, Lanternfishes, and Atlantic Mesopelagic Zoogeography

Part Eight

Order Gasterosteiformes

Pipefishes and Seahorses

Part Nine, Volume One

Orders Anguilliformes and Saccopharyngiformes

Part Nine, Volume Two

Leptocephali

Part Ten

Order Beloniformes

Needlefishes, Sauries, Halfbeaks, and Flyingfishes

\section{MEMOIR II}

The Elementary Chemical Composition of Marine Organisms

by A. P. Vinogradov 


\section{MEMOIR}

SEARS FOUNDATION FOR MARINE RESEARCH

Number I

\section{Fishes of the}

\section{Western North Atlantic}

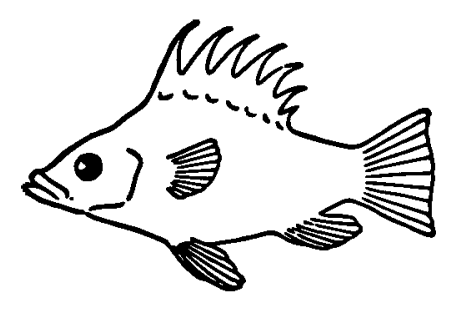

PART THREE

\section{Soft-rayed Bony Fishes}

\section{Class Osteichthyes}

Order Acipenseroidei, Order Lepisostei

Order Isospondyli, Suborder Elopoidea

Suborder Clupeoidea, Suborder Salmonoidea 


\section{Yale}

ISBN 978-1-933789-13-2 (pbk.)

ISBN 978-1-933789-26-2 (e-book)

Issued in paperback by the

Peabody Museum of Natural History, Yale University, New Haven, Connecticut 06511 USA

Part Three first published in hardcover in 1963 by the Sears Foundation for Marine Research,

Bingham Oceanographic Laboratory, Yale University

ISBN 978-0-912532-84-4 (cloth)

Library of Congress Control Number: 49000120

Distributed by Yale University Press NEW HAVEN AND LONDON

Printed in the United States of America Printed on acid-free paper 


\title{
Fishes of the
}

\section{Western North Atlantic}

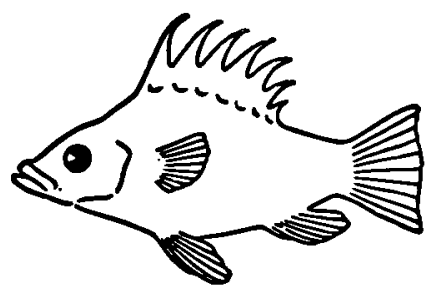

Authors

\author{
HEN RY B. BIGELOW \\ Museum of Comparative Zoology
}

MARGARET G. BRADBURY ROBERT R. MILLER

Hopkins Marine Station The University of Michigan

JOHN R. DYMOND LUIS R. RIVAS

University of Toronto University of Miami

JOHN R. G REELEY WILLIAM C. SCHROEDER

New York Conservation Department Woods Hole Oceanographic Institution

SAMUEL F. HILDEBRAND ROYAL D. SUTTKUS

U.S. Fish and Wildlife Service Tulane University

GILES W. MEAD VADIM D. VLADYKOV

Museum of Comparative Zoology University of Ottawa

NEW HAVEN

SEARS FOUNDATION FOR MARINE RESEARCH, YALE UNIVERSITY 


\title{
Editorial Board
}

\author{
Editor-in-Chief HEN RY B. BIGEL OW Museum of \\ Comparative Zoology, Harvard University
}

CHARLES M. BREDER YNGVEH. OLSEN

American Museum of Natural History Bingham Oceanographic Laboratory

New Tork rale University

DANIEL M. COHEN WILLIAM C. SCHROEDER

U.S. Fish and Wildlife Service Museum of Comparative Zoology

Washington, D.C. Harvard University

GILES W. MEAD LEONARD P. SCHULTZ

Museum of Comparative Zoology United States National Museum

Harvard University Washington, D.C.

DANIEL MERRIMAN

Bingham Oceanographic Laboratory

rale University

\section{JOH N TEE-VAN}

New York Zoological Society

Bronx, N.r. 